\title{
Faktor-Faktor yang Mempengaruhi Kecenderungan Kecurangan Akuntansi Pada LPD di Kabupaten Badung: Peran Keefektifan Pengendalian Internal
}

\author{
Ni Wayan Ayu Putri ${ }^{1}$ \\ I Wayan Suartana ${ }^{2}$ \\ 1,2Fakultas Ekonomi dan Bisnis Universitas Udayana, Indonesia \\ ${ }^{*}$ Correspondences : taxidbali93@gmail.com
}

\begin{abstract}
ABSTRAK
Tujuan dari penelitian ini adalah untuk menganalisis faktor-faktor yang mempengaruhi kecenderungan kecurangan akuntansi pada LPD di Kabupaten Badung dengan keefektifan pengendalian internal sebagai variabel moderasi. Penelitian ini dilakukan di LPD di Kabupaten Badung, jumlah sampel yang digunakan yaitu 93 orang pengawas LPD dengan metode penarikan sampel purposive sampling. Pengumpulan data dilakukan menggunakan pendekatan survei dengan instrumen penelitian yang digunakan adalah kuesioner. Data yang dikumpulkan tersebut kemudian dianalisis menggunakan teknik analisis regresi linier berganda. Hasil penelitian menunjukkan bahwa terdapat pengaruh negatif antara kesesuaian kompensasi terhadap kecenderungan kecurangan akuntansi, asimetri informasi tidak berpengaruh terhadap kecenderungan kecurangan akuntansi, pengendalian internal berpengaruh negatif terhadap kecenderungan kecurangan akuntansi, pengendalian internal mampu memoderasi pengaruh kesesuaian kompensasi terhadap kecenderungan kecurangan akuntansi, pengendalian internal tidak mampu memoderasi pengaruh asimetri informasi terhadap kecenderungan kecurangan akuntansi.
\end{abstract}

Kata Kunci: Kesesuaian Kompensasi; Asimetri Informasi, Pengendalian Internal; Kecenderungan Kecurangan Akuntansi.

\section{Factors Affecting Trends in Accounting Fraud at LPDs in Badung Regency: The Effectiveness of Internal Controls}

\section{ABSTRACT}

The purpose of this study was to analyze the factors that influence the tendency of accounting fraud in LPDs in Badung Regency with the effectiveness of internal control as a moderating variable. This research was conducted in LPD in Badung Regency, the number of samples used were 93 LPD supervisors with purposive sampling method. Data was collected using a survey approach with the research instrument used was a questionnaire. The data collected was then analyzed using multiple linear regression analysis techniques. The results showed that there was a negative influence between the suitability of compensation for the tendency of accounting fraud, information asymmetry had no effect on the tendency of accounting fraud, internal control had a negative effect on the tendency of accounting fraud, internal control was able to moderate the effect of the suitability of compensation on the tendency of accounting fraud, internal control was not able to moderate the effect of information asymmetry on the tendency of accounting fraud.

Keywords: Compensation Suitability; Information Asymmetry; Internal Control; Trends in Accounting Fraud.

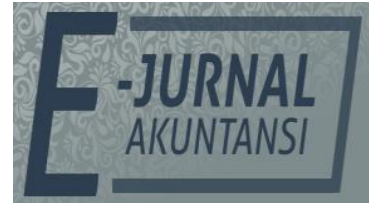

e-ISSN 2302-8556

Vol. 32 No. 1

Denpasar, Januari 2022

Hal. 1-16

DOI:

10.24843/EJA.2022.v32.i01.p01

PENGUTIPAN

Putri, N. W. A. \& Suartana, I. W. (2022). Faktor-Faktor yang Mempengaruhi Kecenderungan Kecurangan Akuntansi Pada LPD di Kabupaten Badung: Peran Keefektifan Pengendalian Internal. E-Jurnal Akuntansi, 32(1), 1-16

RIWAYAT ARTIKEL: Artikel Masuk: 25 Desember 2021 Artikel Diterima: 19 Januari 2022

Artikel dapat diakses : https://ojs.unud.ac.id/index.php/Akuntansi/index 


\section{PENDAHULUAN}

Lembaga Perkreditan Desa (LPD) selaku lembaga keuangan milik desa pakraman di Bali tentunya mempunyai peran yang sangat strategis untuk melayani usaha mikro kecil (UMK) dan masyarakat pedesaan (krama desa). Kegiatan utama LPD menurut Perda Tingkat 1 Bali Nomor 8 Tahun 2002 adalah melakukan penghimpunan dana maupun penyaluran dana dari dan kepada krama desa. LPD bertujuan untuk mendorong pembangunan ekonomi pada masyarakat desa melalui pemberian kredit maupun simpanan dalam bentuk tabungan. Peran LPD sangat penting dalam meningkatkan perekonomian masyarakat. Pentingnya peranan LPD bagi masyarakat, maka pengurus atau pengelola LPD harus meningkatkan produktivitasnya agar mampu bersaing dengan lembaga keuangan lainnya (Putra \& Latrini, 2018). LPD sebagai lembaga keuangan yang terdekat dengan masyarakat desa tentunya diharapkan memiliki kinerja yang baik, memiliki profitabilitas yang tinggi dan tidak mengalami masalah kecurangan akuntansi.

Fenomena tindakan kecurangan (fraud) pada lembaga LPD di Bali, dewasa ini ditemukan pada beberapa LPD di Kabupaten Badung. Salah satu kasus tindakan kecurangan tersebut terjadi pada salah satu LPD di Kuta Selatan yaitu mantan Ketua LPD dipidana akibat melakukan pemalsuan surat. Selain itu, juga ditemukan adanya kasus korupsi yang merupakan tindakan kecurangan yang terjadi pada salah satu LPD di Mengwi, akibat ada lima orang mantan kolektor yang melakukan rekayasa pemberian kredit (Miasa, 2019). Berlandaskan pada permasalahan tersebut, maka penting bagi seluruh LPD di Kabupaten Badung untuk mengawasi seluruh karyawannya agar tidak melakukan tindakan kecurangan akuntansi.

Seiring dengan semakin berkembangnya kegiatan LPD, kepala LPD tidak dapat lagi secara langsung mengawasi aktivitas perusahaan sehingga harus mendelegasikan sebagian tugas, wewenang dan tanggungjawab yang dipikulnya kepada pihak lain yaitu badan pengawas sebagaimana yang diamanatkan dalam Surat Keputusan Gubernur Kepala Daerah Tingkat I Bali. Badan pengawas memiliki tugas pokok untuk menentukan apakah kebijakan dan prosedur yang ditetapkan oleh LPD telah dipatuhi, kemudian bertugas untuk menentukan baik tidaknya pengawasan terhadap kekayaan LPD dan menjamin kehandala informasi yang dihasilkan oleh LPD. Tugas yang menjadi tanggung jawab badan pengawas diharapkan mampu menghasilkan lapran keuangan yang handal dan dapat dipercaya oleh masyarakat serta dapat meminimalisir terjadinya tindak kecurangan (Suarcaya et al., 2018).

Kecurangan atau fraud ini adalah tindakan penipuan yang disengaja, umumnya dalam bentuk suatu kebohongan, penjiplakan dan pencurian (Sayyid, 2015). Terdapat opini bahwa fraud dapat dikatakan sebagai tendensi korupsi dalam definisi dan teminologi karena keterlibatan beberapa unsur yang terdiri dari pengungkapan fakta-fakta menyesatkan, pelanggaran aturan atau penyalahgunaan kepercayaan, dan omisi fakta kritis (Chandra \& Ikhsan, 2015). Kecenderungan kecurangan akuntansi (fraud) dimotivasi oleh tindakan individu untuk memaksimalkan keuntungan pribadi. Motivasi tindakan tersebut karena adanya ketidakpuasan individu atas imbalan yang mereka peroleh dari pekerjaan yang mereka kerjakan. Sistem kompensasi yang sesuai diharapkan dapat 
membuat individu merasa tercukupi sehingga individu tidak melakukan tindakan yang merugikan organisasi termasuk melakukan tindakan kecurangan akuntansi (fraud) (Chandra \& Ikhsan, 2015). Hasil penelitian terdahulu oleh Aswad dkk. (2018) menemukan bahwa kesesuaian kompensasi memiliki pengaruh negatif terhadap kecenderungan kecurangan akuntansi, yakni pemberian kompensasi yang sesuai dapat meminimalkan tindakan karyawan untuk melakukan kecurangan akuntansi, baik melalui pencurian aset, maupun penipuan lainnya karena kesejahteraan karyawan diperhatikan dengan baik oleh perusahaan melalui pemberian kompensasi yang sesuai dan adil (Chandra \& Ikhsan, 2015; Giarini, 2015; Shintadevi, 2016; Suarcaya et al., 2018). Hasil berbeda ditemukan dalam penelitian Alou et al. (2017), Bartenputra (2016), Permatasari et al. (2017), Pratiwi (2018) yang menyatakan bahwa kesesuaian kompensasi tidak berpengaruh signifikan terhadap kecenderungan kecurangan akuntansi.

Kecurangan juga dapat terjadi karena adanya asimetri informasi dalam suatu organisasi (Chandra \& Ikhsan, 2015). Asimetri informasi merupakan keadaan dimana terjadi ketidak seimbangan informasi yang diperoleh oleh prinsipal dan agen. Kondisi tersebut membuka peluang bagi pegawai untuk melakukan kecurangan dengan menyajikan informasi keuangan yang tidak sesuai dengan kondisi yang sebenarnya. Tujuannya semata-mata karena ingin mendapatkan penilaian yang baik atas kinerja yang telah dilakukan dengan memanipulasi informasi keuangan (Permatasari et al., 2017). Menurut hasil penelitian Ardiana (2016), asimetri informasi berpengaruh terhadap kecenderungan kecurangan. Kemudian menurut penelitian Aswad et al. (2018); Bartenputra (2016) asimetri informasi meningkatkan kecenderungan kecurangan akuntansi. Namun hasil berbeda diperoleh dalam penelitian Giarini (2015) yang menemukan hasil bahwa asimetri tidak berpengaruh terhadap kecenderungan kecurangan.

Berlandaskan teori keagenan (Jensen \& Meckling, 1976) yang sering digunakan untuk menjelaskan asimetri informasi. Teori keagenan bermaksud memecahkan dua masalah yang terjadi dalam hubungan keagenan. Salah satunya adalah problem yang muncul bila keinginan atau tujuan dari prinsipal dan agen bertentangan, dan juga disaat prinsipal merasa kesulitan untuk menelusuri apa yang sebenarnya dilakukan oleh agen. Bila agen dan prinsipal berupaya memaksimalkan utilitasnya masing-masing, serta memiliki kenginan dan motivasi yang berbeda, maka agen (manajemen) tidak selalu bertindak sesuai keinginan prinsipal (pemegang saham). Keinginan, motivasi dan utilitas yang tidak sama antara manajemen dan pemegang saham menimbulkan kemungkinan manajemen bertindak merugikan pemegang saham (Aranta, 2013). Untuk menghadapi itu semua tentu diperlukan suatu keefektifan pengendalian internal sehingga bisa meminimalisir terjadinya hal yang disebutkan diatas tadi. Dengan adanya pengendalian internal, maka tindakan kecurangan akan berkurang. Jika keefektifan pengendalian internal baik, maka perilaku fraud akan menurun. Sistem pengendalian internal merupakan proses yang dijalankan untuk memberikan keyakinan memadai tentang pencapaian keandalan laporan keuangan, kepatuhan terhadap hukum, dan efektivitas dan efisiensi operasi (Fawzi, 2011). 
Selain dapat dijadikan sebagai variabel moderasi, keefektifan pengendalian internal juga dapat menjadi variabel independen. Seperti dalam penelitian Alou et al. (2017) yang menyatakan bahwa secara parsial keefektifan pengendalian internal berpengaruh signifikan terhadap Kecenderungan Kecurangan Akuntansi. Sedangkan dalam penelitian Ardiana (2016), Shintadevi (2016), dan Suarcaya et al. (2018) menyatakan bahwa terdapat pengaruh negatif dan signifikan antara keefektifan pengendalian internal dengan kecenderungan kecurangan akuntansi. Artinya semakin tinggi efektivitas sistem pengendalian internal disuatu instansi, maka akan semakin rendah kecenderungan kecurangan akuntansi (fraud). Namun hasil berbeda diperoleh dalam penelitian Giarini (2015) \& Utomo (2018) yang menemukan bahwa Efektivitas pengendalian internal berpengaruh positif terhadap kecenderungan kecurangan akuntansi. Sedangkan penelitian Permatasari et al. (2017) menemukan hasil bahwa keefektifan pengendalian internal tidak berpengaruh terhadap kecenderungan kecurangan. Hal ini disebabkan karena dalam persepsi pegawai baik tidaknya sistem pengendalian internal tidak mempengaruhi kecenderungan seseorang melakukan kecurangan (fraud), hal ini dikarenakan tindakan kecurangan yang dilakukan bisa saja dilakukan diluar sistem pengendalian yang seharusnya dan direncanakan sedekimian rupa dengan melakukan kesepakatan tertentu yang tidak sesuai dengan ketentuan/prosedur sehingga adanya sistem pengendalian internal yang baik tidak lagi menjadi halangan untuk melakukan tindakan kecurangan (fraud).

Adanya inkonsistensi hasil penelitian tersebutlah yang memotivasi peneliti untuk melakukan penelitian kembali mengenai pengaruh asimetri informasi, kesesuaian kompensasi dan keefektifan pengendalian internal terhadap kecenderungan kecurangan (fraud) akuntansi. Farhan et al., (2019) menjelaskan bahwa agar dapat merekonsiliasi hasil yang bertentangan diperlukan pendekatan kontigensi untuk mengidentifikasi variabel lain yang bertindak sebagai variabel pemediasi atau variabel pemoderasi. Teori kontingensi juga dikenal orang sebagai teori situasional. Pendekatan kontingensi (contingency approach) menegaskan bahwa adanya kemungkinan variabel-variabel lain yang bertindak sebagai faktor moderasi atau pemediasi yang mempengaruhi hubungan antara variabel independen dengan variabel dependen (Yasa \& Sari, 2019). Dalam penelitian ini, variabel yang digunakan sebagai pemoderasi adalah keefektifan pengendalian internal.

Kecenderungan kecurangan akuntansi (fraud) dimotivasi oleh tindakan individu untuk memaksimalkan keuntungan pribadi. Motivasi tindakan tersebut karena adanya ketidakpuasan individu atas imbalan yang mereka peroleh dari pekerjaan yang mereka kerjakan. Sistem kompensasi yang sesuai diharapkan dapat membuat individu merasa tercukupi sehingga individu tidak melakukan tindakan yang merugikan organisasi termasuk melakukan tindakan kecurangan akuntansi (fraud) (Chandra \& Ikhsan, 2015). Hasil penelitian terdahulu oleh Aswad et al. (2018) menemukan bahwa kesesuaian kompensasi memiliki pengaruh negatif terhadap kecenderungan kecurangan akuntansi, yakni pemberian kompensasi yang sesuai dapat meminimalkan tindakan karyawan untuk melakukan kecurangan akuntansi, baik melalui pencurian aset, maupun penipuan lainnya karena kesejahteraan karyawan diperhatikan dengan baik oleh perusahaan melalui pemberian kompensasi yang sesuai dan adil. Penelitian serupa oleh 
Chandra \& Ikhsan (2015), Giarini (2015), Shintadevi (2016), Suarcaya et al. (2018) juga menyatakan bahwa kesesuaian kompensasi berpengaruh secara negatif dan signifikan terhadap fraud. Hal ini berarti bahwa apabila kesesuaian kompensasi meningkat, maka perilaku kecurangan/fraud akan menurun. Namun, sebaliknya apabila kesesuaian kompensasi menurun, maka perilaku kecurangan/fraud akan meningkat. Berdasarkan uraian diatas, maka dapat dirumuskan hipotesis sebagai berikut.

$\mathrm{H}_{1}$ : Kesesuaian kompensasi berpengaruh negatif terhadap kecenderungan kecurangan (fraud).

Asimetri informasi merupakan keadaan dimana terjadi ketidak seimbangan informasi yang diperoleh oleh prinsipal dan agen. Kondisi tersebut membuka peluang bagi pegawai untuk melakukan kecurangan dengan menyajikan informasi keuangan yang tidak sesuai dengan kondisi yang sebenarnya. Tujuannya semata-mata karena ingin mendapatkan penilaian yang baik atas kinerja yang telah dilakukan dengan memanipulasi informasi keuangan (Permatasari et al., 2017). Menurut hasil penelitian Ardiana (2016), asimetri informasi berpengaruh terhdap kecenderungan kecurangan. Kemudian menurut penelitian Bartenputra (2016), asimetri informasi berpengaruh signifikan positif terhadap kecenderungan kecurangan akuntansi.

Menurut Chandra \& Ikhsan (2015), bila terjadi asimetri informasi, manajemen perusahaan akan menyajikan laporan keuangan yang bermanfaat bagi mereka, demi motivasi untuk memperoleh kompensasi bonus yang tinggi, mempertahankan jabatan dan lain-lain. Bawahan memiliki informasi yang lebih banyak tentang kapabilitas produksi mereka dibandingan atasan. Ditinjau dari perspektif keagenan, asimetri informasi ini memotivasi bawahan untuk memberikan informasi yang menyesatkan tentang kapabilitas produksi mereka, jadi asimetri informasi berpengaruh positif terhadap kecenderungan kecurangan akuntansi (fraud). Penelitian serupa oleh Aswad et al. (2018) juga memperoleh hasil bahwa Asimetri informasi memiliki pengaruh positif terhadap kecenderungan kecurangan akuntansi. Berdasarkan uraian diatas maka, dapat dirumuskan hipotesis sebagai berikut.

$\mathrm{H}_{2}$ : Asimetri informasi berpengaruh positif terhadap kecenderungan kecurangan (fraud).

Pengendalian Internal merupakan kebijakan atau prosedur yang dilakukan untuk memberikan jaminan bahwa tujuan-tujuan perusahaan dapat dicapai dan untuk mengurangi kerugian atas kemungkinan terjadinya ancaman keamanan dalam informasi. Pengendalian internal sebagai suatu proses yang dijalankan oleh dewan komisaris, manajemen dan personel lain entitas yang didesain untuk memberikan keyakinan memadai tentang pencapaian tiga golongan tujuan berikut ini keandalan pelaporan keuangan, efektivitas dan efesiensi operasi dan kepatuhan terhadap hukum peraturan yang berlaku. Komponen fraud triangle menjelaskan peluang terjadinya fraud dapat di minimalkan oleh dengan memperkuat pengendalian internal (Suarcaya et al., 2018).

Pengendalian internal dirancang untuk menyediakan keyakinan yang menandai berkaitan dengan tujuan beberapa kategori yaitu efektivitas dan efisien kegiatan, keandalan pelaporan keuangan dan ketaatan pada peraturan dan ketentuan yang berlaku. Pengendalian internal sangat penting bagi suatu entitas, 
antara lain untuk memberikan perlindungan terhadap suatu entitas dari kelemahan manusia serta mengurangi tindakan untuk melakukan kecurangan yang tidak sesuai dengan aturan (Fitri, 2016).

Penelitian Eliza (2015) menunjukan bahwa sistem pengendalian intern berpengaruh negatif dan signifikan terhadap tingkat kecenderungan kecurangan akuntansi. Jadi, semakin efektif sistem pengendalian intern maka kecenderungan kecurangan akunansi semakin berkurang. Penelitian Alou et al. (2017) yang menyatakan bahwa secara parsial keefektifan pengendalian internal berpengaruh signifikan terhadap kecenderungan kecurangan akuntansi. Sedangkan dalam penelitian Ardiana (2016), Shintadevi (2016), dan Suarcaya et al. (2018) menyatakan bahwa terdapat pengaruh negatif dan signifikan antara keefektifan pengendalian internal dengan kecenderungan kecurangan akuntansi. Hal ini berarti bahwa kecenderungan kecurangan akuntansi dapat dikurangi jika sistem pengendalian internal yang efektif diterapkan dalam perusahaan. Semakin tinggi sistem pengendalian internal maka semakin menurun kecenderungan kecurangan akuntansi. Berdasarkan uraian tersebut maka disusun hipotesis yaitu sebagai berikut.

$\mathrm{H}_{3}$ : Pengendalian internal berpengaruh negatif terhadap kecenderungan kecurangan akuntansi.

Teori atribusi menyatakan bahwa tindakan seorang pemimpin maupun orang yang diberikan wewenang dipengaruhi oleh atribut penyebab. Seseorang cenderung akan mengeluarkan potensi terbaiknya untuk mendapatkan kompensasi. Kompensasi merupakan hal yang bisa mempengaruhi tindakan maupun perilaku seseorang dalam organisasi. Seseorang cenderung berperilaku curang untuk memaksimalkan keuntungan pribadinya. Dengan adanya kompensasi yang sesuai yang diberikan kepada manajemen, maka diharapkan manajemen cenderung bertindak sesuai keinginan perusahaan dan menghindari tindakan menyimpang agar tetap mendapatkan kompensasi. Kompensasi yang sesuai menjadi bagian yang sangat penting bagi kinerja karyawan serta keberhasilan organisasi (Luthans, 2011). Pemberian kompensasi yang sesuai serta diperkuat dengan pengendalian internal yang efektif tentu akan membuat manajemen perusahaan berbuat sesuai dengan apa yang telah ditetapkan oleh perusahaan.

Pendapat ini didukung oleh Wright et al. (2001) yang menyatakan bahwa insentif, pengawasan serta sistem yang berjalan dengan baik dapat mencegah perilaku curang manajemen perusahaan. Penelitian ini berpendapat bahwa pemberian kompensasi yang sesuai akan menurunkan kecurangan manajemen perusahaan. Hal serupa juga diperleh dalam penelitian Aswad et al. (2018) yang menyatakan bahwa keefektifan pengendalian internal mampu memoderasi memperkuat pengaruh negatif kesesuaian kompensasi terhadap kecenderungan kecurangan akuntansi. Jadi, dilakukannya pengendalian internal yang efektif didalam perusahaan mampu memperkuat pengaruh negatif kesesuaian kompensasi yang telah diberikan perusahaan kepada karyawan guna menekan kecenderungan kecurangan akuntansi yang dilakukan oleh karyawan atau manajemen. Berdasarkan uraian tersebut maka disusun hipotesis yaitu sebagai berikut. 
$\mathrm{H}_{4}$ : Keefektifan pengendalian internal mampu memoderasi pengaruh kesesuaian kompensasi terhadap kecenderungan kecurangan (fraud).

Kecenderungan kecurangan yang terjadi dapat diturunkan dengan meningkatkan keefektifan pengendalian internal atau dengan kata lain meningkatkan suatu pengawasan internal yanng efektif. Oleh karena itu, dalam penelitian ini menggunakan variabel keefektifan pengendalian internal sebagai variabel moderasi. Jika pengendalian internal suatu perusahaan lemah maka kemungkinan terjadinya kesalahan dan kecurangan semakin besar. Sebaliknya, jika pengendalian internalnya kuat maka kemungkinan terjadinya kecurangan dapat diperkecil (Saftarini et al., 2015).

Berlandaskan teori keagenan (Jensen \& Meckling, 1976)) yang sering digunakan untuk menjelaskan asimetri informasi. Teori keagenan bermaksud memecahkan dua problem yang terjadi dalam hubungan keagenan. Salah satunya adalah problem yang muncul bila keinginan atau tujuan dari prinsipal dan agen bertentangan, dan juga disaat prinsipal merasa kesulitan untuk menelusuri apa yang sebenarnya dilakukan oleh agen. Bila agen dan prinsipal berupaya memaksimalkan utilitasnya masing-masing, serta memiliki kenginan dan motivasi yang berbeda, maka agen (manajemen) tidak selalu bertindak sesuai keinginan prinsipal (pemegang saham). Keinginan, motivasi dan utilitas yang tidak sama antara manajemen dan pemegang saham menimbulkan kemungkinan manajemen bertindak merugikan pemegang saham (Aranta, 2013). Untuk menghadapi itu semua tentu diperlukan suatu keefektifan pengendalian internal sehingga bisa meminimalisir terjadinya hal yang disebutkan diatas tadi. Dengan adanya pengendalian internal, maka tindakan kecurangan akan berkurang. Jika keefektifan pengendalian internal baik, maka perilaku fraud akan menurun. Sistem pengendalian internal merupakan proses yang dijalankan untuk memberikan keyakinan memadai tentang pencapaian keandalan laporan keuangan, kepatuhan terhadap hukum, dan efektivitas dan efisiensi operasi (Fawzi, 2011)Menurut penelitian Aswad et al. (2018), Keefektifan pengendalian internal dapat memperlemah pengaruh positif asimetri informasi terhadap kecenderungan kecurangan akuntansi. Berdasarkan uraian tersebut maka disusun hipotesis yaitu sebagai berikut.

$\mathrm{H}_{5}$ : Keefektifan pengendalian internal mampu memoderasi pengaruh asimetri informasi terhadap kecenderungan kecurangan.

\section{METODE PENELITIAN}

Penelitian ini akan dilakukan pada LPD di Kabupaten Badung. Alasan penelitian dilakukan pada LPD di Kabupaten Badung karena ditemukan adanya fenomena masalah terkait kecenderungan kecurangan yang dilakukan oleh beberapa LPD di Kabupaten Badung. Ukuran sampel dalam penelitian ini ditentukan berdasarkan pendekatan Slovin. Sampel adalah bagian dari jumlah dan karakteristik yang dimiliki oleh populasi (Sugiyono, 2016). Sampel dalam penelitian ini adalah 93 orang Pengawas LPD di Kabupaten Badung. Alasan pemilihan kriteria tersebut agar pemilihan responden dalam penelitian ini menjadi lebih representatif, sehingga ditentukan responden yang terlibat secara langsung dalam aktivitas keuangan di LPD. 
Variabel kompensasi finansial diukur dengan menggunakan indikator yang dikembangkan oleh Arifah (2017), yaitu 1) gaji sesuai dengan pekerjaan; 2) imbalan tunai setiap keiatan diluar jam kerja; 3) insentif sesuai dengan prestasi 4) bayaran diluar jam kerja; 4) penghargaan; 5) asuransi; 6) fasilitas kerja; 7) tunjangan sesuai kebutuhan. Variabel asimetri informasi diukur dengan menggunakan kuesioner yang dikembangkan oleh Randiza et al. (2016). Indikator untuk mengukur informasi asimetri adalah informasi yang dimiliki bawahan dibandingkan atasan, hubungan input-output yang ada dalam operasi internal kinerja potensial, teknis pekerjaan, mampu menilai dampak potensial, pencapaian bidang kegiatan. Variabel pengendalian internal diukur dengan 12 buah pertanyaan dengan 5 indikator yang mengacu pada penelitian Shintadevi (2016) yaitu lingkungan pengendalian, penilaian risiko, kegiatan pengendalian, informasi dan komunikasi, pemantauan/pengawasan. Instrumen yang digunakan untuk mengukur kecenderungan kecurangan akuntansi terdiri dari empat belas pernyataan yang mengacu pada SPAP seksi 316 (2001) dan yang dikembangkan dalam penelitian Aryani (2016). Indikator yang digunakan adalah kecenderungan untuk melakukan manipulasi, pemalsuan, atau perubahan catatan akuntansi atau dokumen pendukungnya, kecenderungan untuk melakukan penyajian yang salah atau penghilangan peristiwa, transaksi, atau informasi yang signifikan dari laporan keuangan, kecenderungan untuk melakukan salah menerapkan prinsip akuntansi secara sengaja, kecenderungan untuk melakukan penyajian laporan keuangan yang salah akibat pencurian (penyalahgunaan/ penggelapan) terhadap aktiva yang membuat entitas membayar barang/jasa yang tidak terima dan kecenderungan untuk melakukan penyajian laporan keuangan yang salah akibat perlakuan yang tidak semestinya terhadap aktiva dan disertai dengan catatan atau dokumen palsu dan dapat menyangkut satu atau lebih individu di antara manajemen, karyawan atau pihak ketiga yang dikembangkan oleh penelitian Udayani (2016) dengan menggunakan skala likert 1-4.

Teknik yang digunakan dalam pengambilan sampel penelitian ini adalah purposive sampling. Adapaun responden yang dipilih harus merupakan pengawas LPD yang memilki masa jabatan minimal satu tahun dan terlibat secara langsung dalam aktivitas keuangan di LPD. Penelitian ini menggunakan teknik analisis data, yaitu dengan analisis regresi linier berganda. Analisis data menggunakan alat bantu program Statistical Program for Social Sciences (SPSS). Teknik analisis regresi linier berganda digunakan untuk menguji pengaruh kesesuaian kompensasi, dan informasi asimetri, terhadap kecenderungan kecurangan (fraud) dengan keefektifan pengendalian internal sebagai variabel moderasi. Pengujian hipotesis dalam penelitian ini menggunakan Analisis Regresi Moderasi (Moderated Regression Analysis). Ghozali (2016) menyatakan bahwa uji interaksi atau sering disebut Moderated Regression Analysis (MRA) merupakan aplikasi khusus regresi berganda linear di mana dalam persamaan regresinya mengandung unsur interaksi (perkalian dua atau lebih independen). Menurut Ghozali (2016), tujuan analisis ini untuk mengetahui apakah variabel moderating akan memperkuat atau memperlemah hubungan antara variabel independen dan variabel dependen. Terdapat tiga model pengujian regresi dengan variabel moderating, yaitu uji interaksi (Moderated Regression Analysis), uji nilai selisih mutlak, dan uji residual. Dalam penelitian ini akan digunakan uji MRA. MRA menggunakan pendekatan 
analitik yang mempertahankan integritas sampel dan memberikan dasar utuk mengontrol pengaruh variabel moderator. Metode ini dilakukan dengan menambahkan variabel perkalian antara variabel bebas dengan variabel moderatingnya.

Keterangan:

$$
Y=a+b_{1} X_{1}+b_{2} X_{2}+b_{3} X_{3}+b_{4} X_{1} X_{3}+b_{5} X_{2} X_{3}+\varepsilon
$$

$\mathrm{Y} \quad=$ kecenderungan kecurangan akuntansi (fraud)

a $\quad=$ Konstanta

$\mathrm{b} \quad=$ Koefisien Regresi

$\mathrm{X}_{1} \quad=$ Kesesuaian kompensasi

$\mathrm{X}_{2} \quad=$ Asimetri informasi

$\mathrm{X}_{3} \quad=$ keefektifan pengendalian internal

\section{HASIL DAN PEMBAHASAN}

Pengujian validitas menggunakan teknik Product Moment pada tingkat signifikan 5 persen. Berdasarkan hasil analisis validitas dengan program SPSS dapat dilihat pada Tabel 1. Seluruh koefisien korelasi dari indikator variabel yang diuji nilainya lebih besar dari 0,30 ( $\mathrm{r}>0,3)$. Hal tersebut menunjukan bahwa seluruh indikator variabel Kesesuaian Kompensasi, Informasi Asimetri, Pengendalian Internal dan Kecendrungan Kecurangan Akuntansi yang terdapat pada penelitian ini terbukti valid.

Tabel 1. menunjukan masing-masing nilai Cronbach's Alpha pada tiap instrumen tersebut lebih besar dari 0,6 (Cronbach's Alpha> 0,60). Hal tersebut menunjukan bahwa variabel Kesesuaian Kompensasi, Informasi Asimetri, Pengendalian Internal dan Kecendrungan Kecurangan Akuntansi reliabel, sehingga dapat digunakan untuk melakukan penelitian.

Data yang digunakan dalam penelitian ini berdasarkan hasil jawaban kuesioner yang disebarkan dari tanggal 09 Januari 2021 Sampai dengan tanggal 30 Juni 2021. Hasil tabulasi data disajikan pada Lampiran 3. Deskripsi data variabel penelitian terdiri dari jumlah pengamatan, nilai minimum, nilai maksimum, nilai rata-rata, dan deviasi standar. Tabel 2. menyajikan hasil uji statistik deskriptif.

Nilai minimum variabel Kesesuaian Kompensasi sebesar 2,780, nilai maksimum sebesar 3,380, dan nilai rata-rata sebesar 2,670. Nilai rata-rata sebesar 2,67 menunjukkan bahwa rata-rata Pengawas LPD cenderung setuju dengan Kesesuaian Kompensasi harus dilakukan oleh organisasi sebagai distribusi karyawan kepada organisasi. Nilai minimum Asimetri Informasi sebesar 2,000 dan nilai maksimum sebesar 4,000. Nilai rata-rata sebesar 3,060 yang mempunyai arti bahwa rata-rata Pengawas LPD cenderung setuju Asimetri Informasi merupakan ketidakseimbangan informasi yang dimiliki oleh atasan dan bawahan. Nilai maksimum Keefektifan Pengendalian Internal sebesar 4,170 dan nilai minimum sebesar 2,000. Nilai rata-rata sebesar 3,000 yang berarti bahwa rata-rata Pengawas LPD cenderung setuju sistem pengendalian internal merupakan proses yang dijalankan untuk memberikan keyakinan memadai tentang pencapaian keandalan laporan keuangan. Kecenderungan Kecurangan Akuntansi (fraud) memiliki nilai minimum sebesar 2,330 dan nilai maksimum sebesar 3,830. Nilai rata-rata sebesar 3,400, yang berarti bahwa rata-rata Pengawas LPD cenderung 
setuju Kecenderungan Kecurangan Akuntansi adalah keinginan untuk melakukan segala sesuatu untuk memperoleh keuntungan dengan cara yang tidak jujur.

\section{Tabel 1. Uji Validitas Instrumen}

\begin{tabular}{|c|c|c|c|c|c|}
\hline Pertanyaan & $\begin{array}{c}\text { Koefisien } \\
\text { Korelasi }\end{array}$ & Signifikansi & Keterangan & $\begin{array}{l}\text { Cronbach's } \\
\text { Alpha }\end{array}$ & Keterangan \\
\hline \multicolumn{6}{|c|}{ Kesesuaian Kompensasi } \\
\hline 1. $(X 1.1)$ & 0,607 & 0,00 & Valid & \multirow{8}{*}{0,750} & \multirow{8}{*}{ Reliabel } \\
\hline 2. $(X 1.2)$ & 0,424 & 0,00 & Valid & & \\
\hline 3. $(X 1.3)$ & 0,627 & 0,00 & Valid & & \\
\hline 4. (X1.4) & 0,439 & 0,00 & Valid & & \\
\hline 5. $(X 1.5)$ & 0,524 & 0,00 & Valid & & \\
\hline 6. $(X 1.6)$ & 0,633 & 0,00 & Valid & & \\
\hline 7. $(X 1.7)$ & 0,554 & 0,00 & Valid & & \\
\hline 8. $(X 1.8)$ & 0,437 & 0,00 & Valid & & \\
\hline \multicolumn{6}{|c|}{ Informasi Asimetri } \\
\hline 1. $(X 2.1)$ & 0,580 & 0,00 & Valid & \multirow{6}{*}{0,714} & \multirow{6}{*}{ Reliabel } \\
\hline 2. $(X 2.2)$ & 0,628 & 0,00 & Valid & & \\
\hline 3. $(\mathrm{X} 2.3)$ & 0,656 & 0,00 & Valid & & \\
\hline 4. $(X 2.4)$ & 0,687 & 0,00 & Valid & & \\
\hline 5. $(X 2.5)$ & 0,765 & 0,00 & Valid & & \\
\hline 6. $(X 2.6)$ & 0,526 & 0,00 & Valid & & \\
\hline \multicolumn{6}{|c|}{ Pengendalian Internal } \\
\hline 1. $(\mathrm{X} 3.1)$ & 0,415 & 0,00 & Valid & \multirow{12}{*}{0,841} & \multirow{12}{*}{ Reliabel } \\
\hline 2. $(\mathrm{X} 3.2)$ & 0,370 & 0,01 & Valid & & \\
\hline 3. $(\mathrm{X} 3.3)$ & 0,363 & 0,01 & Valid & & \\
\hline 4. $(X 3.4)$ & 0,484 & 0,00 & Valid & & \\
\hline 5. $(X 3.5)$ & 0,567 & 0,00 & Valid & & \\
\hline 6. $(X 3.6)$ & 0,564 & 0,00 & Valid & & \\
\hline 7. $(X 3.7)$ & 0,521 & 0,00 & Valid & & \\
\hline 8. $(\mathrm{X} 3.8)$ & 0,504 & 0,00 & Valid & & \\
\hline 9. (X3.9) & 0,395 & 0,01 & Valid & & \\
\hline 10. (X3.10) & 0,392 & 0,01 & Valid & & \\
\hline 11. (X3.11) & 0,539 & 0,00 & Valid & & \\
\hline 12. (X3.12) & 0,386 & 0,01 & Valid & & \\
\hline \multicolumn{6}{|c|}{ Kecendrungan Kecurangan Akuntansi } \\
\hline 1. (Y1.1) & 0,332 & 0,02 & Valid & \multirow{12}{*}{0,799} & \multirow{12}{*}{ Reliabel } \\
\hline 2. (Y1.2) & 0,323 & 0,03 & Valid & & \\
\hline 3. (Y1.3) & 0,426 & 0,00 & Valid & & \\
\hline 4. (Y1.4) & 0,339 & 0,03 & Valid & & \\
\hline 5. (Y1.5) & 0,319 & 0,03 & Valid & & \\
\hline 6. (Y1.6) & 0,438 & 0,00 & Valid & & \\
\hline 7. (Y1.7) & 0,565 & 0,00 & Valid & & \\
\hline 8. (Y1.8) & 0,635 & 0,00 & Valid & & \\
\hline 9. (Y1.9) & 0,344 & 0,01 & Valid & & \\
\hline 10. (Y1.10) & 0,401 & 0,00 & Valid & & \\
\hline 11. (Y1.11) & 0,528 & 0,00 & Valid & & \\
\hline 12. (Y1.12) & 0,331 & 0,02 & Valid & & \\
\hline
\end{tabular}

Sumber: Data Penelitian, 2021 
Tabel 2. Hasil Uji Statistik Deskriptif

\begin{tabular}{lccccc}
\hline Keterangan & $\mathrm{N}$ & Minimum & Maximum & Mean & Std. Deviation \\
\hline $\begin{array}{l}\text { Kesesuaian } \\
\text { Kompensasi }\end{array}$ & 87 & 2,380 & 3,380 & 2,670 & 0,240 \\
$\begin{array}{l}\text { Asimetri Informasi } \\
\text { Keefektifan }\end{array}$ & 87 & 2,000 & 4,000 & 3,060 & 0,500 \\
$\begin{array}{l}\text { Pengendalian Internal } \\
\text { kecenderungan } \\
\text { kecurangan akuntansi } \\
(\text { fraud })\end{array}$ & 87 & 2,000 & 4,170 & 3,010 & 0,350 \\
\hline
\end{tabular}

Sumber: Data Penelitian, 2021

Pengujian data dalam penelitian ini menggunakan teknik analisis regresi linier berganda. Perhitungan koefisien regresi linier berganda dilakukan dengan analisis regresi melalui software SPSS 24.0 for Windows, diperoleh hasil yang ditunjukan pada Tabel 3. Berdasarkan hasil analisis regresi linier berganda seperti yang disajikan pada Tabel 3., maka dapat dibentuk persamaan model MRA prediksian Kecenderungan Kecurangan akuntansi $(\hat{Y})$ sebagai berikut.

$\hat{Y}=36,032-0,342 X_{1}+0,230 X_{2}-0,137 X_{3}-0,008 X_{1} \cdot X_{3}-0,005 X_{2} \cdot X_{3}$

Tabel 3. menunjukkan nilai koefisien determinasi $\left(R^{2}\right)$ sebesar 0,729 mempunyai arti bahwa sebesar $72,9 \%$ variasi tingkat Kecendrungan Kecurangan Akuntansi dipengaruhi oleh variasi Kesesuaian Kompensasi $\left(X_{1}\right)$, Informasi Asimetri $\left(X_{2}\right)$, Pengendalian Internal $\left(X_{3}\right)$ variabel interaksi variabel Kesesuaian Kompensasi dengan Pengendalian Internal, dan variabel Informasi Asimetri dengan pengendalian internal, sedangkan sisanya sebesar $27,1 \%$ djelaskan oleh faktor lain yang tidak dimasukkan ke dalam model.

Tabel 3. Hasil Analisis Regresi Linier Berganda

\begin{tabular}{|c|c|c|c|c|c|}
\hline & Model & B & Std. Error & $\mathrm{t}$ & Sig. \\
\hline \multirow[t]{10}{*}{1} & (Constant) & 36,032 & 5,585 & 6,451 & 0,000 \\
\hline & Kesesuaian Kompensasi & $-0,342$ & 0,150 & $-2,276$ & 0,026 \\
\hline & Informasi Asimetri & 0,230 & 0,165 & 1,395 & 0,167 \\
\hline & Pengendalian Internal & $-0,137$ & 0,070 & $-1,937$ & 0,028 \\
\hline & X1.X3 & $-0,008$ & 0,004 & $-2,027$ & 0,035 \\
\hline & $\mathrm{X} 2 . \mathrm{X} 3$ & $-0,005$ & 0,004 & $-1,029$ & 0,307 \\
\hline & $\mathrm{F}$ & 2,833 & & & \\
\hline & Sig. F & 0,021 & & & \\
\hline & R Squared & 0,729 & & & \\
\hline & Adjusted R Squared & 0,686 & & & \\
\hline
\end{tabular}

Sumber: Data Penelitian, 2021

Hasil penelitian menunjukkan bahwa terdapat pengaruh negatif antara kesesuaian kompensasi terhadap kecenderungan kecurangan (fraud) Akuntansi. Kompensasi merupakan hal yang berpengaruh terhadap perilaku karyawan, seseorang cenderung akan berperilaku tidak etis dan berlaku curang untuk memaksimalkan keuntungan untuk dirinya sendiri. Karyawan akan melakukan kecurangan karena ketidakpuasaan atau kekecewaan dengan hasil atau kompensasi yang mereka terima atas apa yang telah dikerjakan.

Hasil penelitian sesuai dengan penelitian Shintadevi (2016) dan Thoyibatun (2012). Penyebab terjadinya perilaku tidak etis adalah kurangnya pengawasan manajemen di mana hal tersebut dapat memberikan kesempatan 
karyawan untuk melakukan tindakan tidak etis yang dapat merugikan instansi atau lembaga itu sendiri, ketidakpuasaan dan kekecewaan karyawan dengan hasil atau kompensasi yang diperoleh di dalam suatu perusahaan atas apa yang telah mereka kerjakan, dan ketidaktaatan pada aturan akuntansi juga dapat memicu terjadinya perilaku tidak etis. Sistem kompensasi yang sesuai diharapkan dapat membuat individu merasa tercukupi sehingga individu tidak melakukan tindakan yang merugikan organisasi termasuk melakukan tindakan kecurangan akuntansi (fraud). Bagi karyawan kompensasi merupakan faktor yang menentukan tingkat kesejahteraan, sedang bagi organisasi kompensasi merupakan komponen biaya yang mempengaruhi tingkat efisiensi dan profitabilitas (Thoyibatun, 2012).

Hasil penelitian menunjukkan bahwa Asimetri informasi tidak berpengaruh terhadap kecenderungan kecurangan (fraud) Akuntasi. Hasil penelitian ini sejalan dengan yang dilakukan oleh Saftarini et al. (2015) menyatakan bahwa timbulnya tindak kecurangan karena terdapat peluang bagi pihak pengelola dana untuk melakukan kecurangan. Sedangkan pihak yang dapat melakukan kecurangan hanya pihak internal instansi yang mengetahui selukbeluk dalam hal pembuatan dan penyajian laporan keuangan yang dikarenak kurangnya transparansi atau keterbukaan dalam hal pengelolaan keuangan.

Hasil penelitiani ini konsisten dengan penelitian yang dilakukan Aranta (2013) yang menyebutkan bahwa keberadaan asimetri informasi tidak dapat menekan ataupun meminimalkan kecendrungan kecurangan. Kondisi ini dapat diartikan bahwa terdapat budaya tanggung-jawab pada masing-masing LPD utamanya pada posisi pengawas, sehingga rasa tanggung-jawab memiliki pekerjaan dapat dilaksakan secara bersama-sama.

Hasil penelitian menunjukkan bahwa pengendalian internal berpengaruh negatif terhadap kecenderungan kecurangan (fraud) akuntansi. Hasil penelitian sejalan dengan temuan Adelin (2013) yang menjelaskan bahwa semakin rendah tingkat pengendalian internal, maka kemungkinan untuk melakukan kecurangan akuntansi semakin tinggi. Sebaliknya, jika tingkat pengendalian internal yang ada di dalam entitas atau organisasi dapat berjalan baik maka kecenderungan melakukan kecurangan akuntansi semakin rendah sehingga proses pelaporan keuangan yang dihasilkan dapat memberikan informasi yang relevan.

Pengendalian internal mampu memengaruhi relevansi informasi yang merujuk pada kemampuan untuk keputusan manajer dengan melakukan perubahan mengenai hasil atau konsekuensi suatu tindakan atau kejadian. Selain itu, informasi yang disajikan harus memiliki nilai prediksi dan umpan balik, sehingga pada waktu yang bersamaan harus disampaikan dengan tepat waktu (relevan). Sedangkan reliabel merujuk ke arah penyajian informasi yang dapat diverifikasi dan jujur (Riahi \& Belkaoui, 2000).

Hasil penelitian menunjukkan bahwa pengendalian internal mampu memoderasi pengaruh kesesuaian kompensasi terhadap kecenderungan kecurangan (fraud) akuntansi. Pengendalian Internal memegang peranan penting dalam memperkuat pengaruh kompensasi dalam menekan terjadinya kecurangan. Kondisi ini memungkinkan terjadi karena penerapan sistim administrasi yang belum sesuai dengan peraturan, atau mungkin karena sistem pengendalian internal LPD di Kabupaten Badung memiliki sistem yang sangat mapan. Pengendalian internal yang dimaksud melalui struktur organisasi yang 
jelas dan terarah, yaitu pembatasan kewenangan melakukan transaksi keuangan dengan membatasi kewenangan pembukuan pada petugas tertentu saja.

Selain struktur organisasi, pengawasan ganda juga dilakukan di LPD Kabupaten Badung yaitu dengan cara pembuatan dua dokumen yang berbeda dari sumber yang sama selanjutnya kedua dokumen tersebut dicocokkan satu sama lain. Penelitian yang dilakukan oleh Monigka (2010) tentang pengaruh keefektifan pengendalian intern terhadap kecenderungan akuntansi, hasil penelitiannya menunjukkan bahwa pengendalian internal yang efektif mengurangi kecenderungan kecurangan akuntansi. Sehingga skema kompensasi yang sudah sesuai diperkuat dengan pengendalian internal yang mapan dapat menekan terjadinya kecendrungan kecurangan.

Hasil penelitian menunjukkan bahwa pengendalian internal tidak mampu memoderasi pengaruh asimetri informasi terhadap kecenderungan kecurangan (fraud) akuntansi. Keberadaan pengendalian internal tidak mampu memperkuat ataupun memperlemah pengaruh asimetri informasi terhadap kecenderungan kecurangan (fraud) akuntansi.

Pengendalian yang efektif dalam keadaan yang optimal mampu memberikan pengawasan dan saran mengenai hasil atau konsekuensi suatu tindakan atau kejadian. Informasi yang disajikan selama melakukan pengendalian internal tidak memiliki nilai prediksi dan umpan balik, sehingga pada waktu yang bersamaan tidak dapat disampaikan dengan tepat waktu (relevan). Sehingga nilai relevansi pengendalian internal tidak dapat memoderasi pengaruh kesesuaian kompensasi terhadap kecendrungan kecurangan (Riahi \& Belkaoui, 2000).

\section{SIMPULAN}

Kesesuaian kompensasi dan pengendalian internal berpengaruh negatif pada kecenderungan kecurangan (fraud). Hal ini berarti bahwa semakin tinggi kesesuaian kompensasi, maka akan menurunkan kecenderungan kecurangan (fraud) yang terjadi di LPD kabupaten Badung. Sementara itu, asimetri informasi tidak berpengaruh terhadap kecenderungan kecurangan (fraud). Hal ini berarti bahwa keberadaan Asimetri informasi tidak merubah kecenderungan kecurangan (fraud) yang terjadi di LPD kabupaten Badung. Pengendalian internal memperlemah pengaruh kesesuaian kompensasi terhadap kecenderungan kecurangan (fraud). Hasil penelitian menunjukkan bahwa Pengendalian Internal tidak mampu memoderasi Pengaruh Asimetri Informasi Terhadap Kecenderungan kecurangan (fraud). Pengendalian internal tidak dapat memoderasi hubungan antara asimetri informasi terhadap kecenderungan kecurangan (fraud) yang terjadi di LPD kabupaten Badung.

Penelitian ini hanya menggunakan populasi penelitian di LPD kabupaten Badung. Hal ini mengakibatkan kemungkinan hasil penelitian ini tidak bisa digeneralisasikan untuk semua tingkat pemerintah daerah kabupaten/kota di seluruh LPD di Bali. Penelitian selanjutnya disarankan untuk menggunakan variasi variabel penelitian yang diindikasikan dapat memperkuat ataupun memperlemah kemungkinan terjadinya kecurangan akuntansi di LPD. 


\section{REFERENSI}

Adelin, V. (2013). Pengaruh Pengendalian Internal, Ketaatan Aturan Akuntansi, dan Perilaku Tidak Etis Terhadap Kecenderungan Kecurangan Akuntansi (Studi Empiris pada BUMN di Kota Padang). Skripsi Sarjana pada Program Sarjana Fakultas Ekonomi Universitas Negeri Padang.

Alou, S. D., Ilat, V., \& Gamaliel, H. (2017). Pengaruh Kesesuaian Kompensasi, Moralitas Manajemen, Dan Keefektifan Pengendalian Internal Terhadap Kecenderungan Kecurangan Akuntansi Pada Perusahaan Konstruksi Di Manado. Going Concern: Jurnal Riset Akuntansi, 12(1), 139-148. https://doi.org/10.32400/gc.12.01.17146.2017

Aranta, Z. P. (2013). Pengaruh Moralitas Aparat dan Asimetri Informasi terhadap Kecenderungan Kecurangan Akuntansi (Studi Empiris Pemerintah Kota Sawahlunto). Jurnal Program Studi Akuntansi Universitas Negeri Padan, 3(2), 1115.

Ardiana, W. (2016). Analisis Faktor-Faktor Yang Mempengaruhi Kecenderungan Kecurangan Akuntansi (Studi empiris pada Dinas Kota Surakarta). Universitas Muhammadiyah Surakarta.

Arifah, A. (2017). Pengaruh Ketaatan Aturan Akuntansi, Keefektifan Pengendalian Internal, Kesesuaian Kompensasi, Keadilan Prosedural, Dan Komitmen Organisiasi Terhadap Kecenderungan Kecurangan Akuntansi (Studi pada Perguruan Tinggi Negeri di Daerah Istimewa Yogyakarta). Universitas Negeri Yogyakarta.

Aryani, T. (2016). Pengaruh Efektivitas Pengendalian Internal, Kesesuaian Kompensasi Dan Asimetri Informasi Terhadap Kecenderungan Kecurangan Akuntansi. Unika Soegijapranata Semaran.

Aswad, H., Hasan, A., \& Indrawati, N. (2018). Faktor-Faktor Yang Mempengaruhi Kecenderungan Kecurangan Akuntansi Dengan Keefektifan Pengendalian Internal Sebagai Variabel Moderasi (Studi pada Perusahaan Perkebunan Kelapa Sawit Swasta Di Provinsi Riau). Jurnal Akuntansi, 6(2), 221-234.

Bartenputra, A. (2016). Pengaruh Kesesuaian Kompensasi, Ketaatan Akuntansi Dan Asimetri Informasi Terhadap Kecenderungan Kecurangan Akuntansi (Studi empiris pada SKPD Kota Bukittinggi). Jurnal Akuntansi, 4(2).

Chandra, D., \& Ikhsan, S. (2015). Determinan Terjadinya Kecenderungan Kecurangan Akuntansi (Fraud) Pada Dinas Pemerintah Se Kabupaten Grobogan. Accounting Analysis Journal, 4(3). https:// doi.org/10.15294/aaj.v4i3.8308

Eliza, Y. (2015). Pengaruh Moralitas Individu Dan Pengendalian Internal Terhadap Kecenderungan Kecurangan Akuntansi (Studi Empiris Pada SKPD di Kota Padang). Jurnal Akuntansi, 4(1).

Farhan, M., Helmy, H., \& Afriyenti, M. (2019). Pengaruh Machiavellian Dan Love Of Money Terhadap Persepsi Etika Penggelapan Pajak Dengan Religiusitas Sebagai Variabel Moderasi. Jurnal Eksplorasi Akuntansi, 1(1), 470-486.

Fawzi, M. G. H. (2011). Analisis Pengaruh Keefektifan Pengendalian Internal, Persepsi Kesesuaian Kompensasi, Moralitas Manajemen Terhadap Perilaku Tidak Etis dan Kecederungan Kecurangan Akuntansi. E-Journal Universitas Diponegoro, 7(1), 45-96.

Fitri, Y. (2016). Pengaruh keefektifan sistem pengendalian internal, ketaatan 
akuntansi, asimteri informasi dan moralitas individu terhadap kecenderungan kecurangan akuntansi dengan perilaku tidak etis sebagai variabel intervening (Studi empiris pada Satuan Kerja Perangkat. Jom Fekon, $3(1)$.

Ghozali, I. (2016). Aplikasi Analisis Multivariate dengan Program IBM SPSS 23. Semarang: Badan Penerbit Universitas Diponegoro.

Giarini, F. L. (2015). Pengaruh Efektivitas Pengendalian Internal, Kesesuaian Kompensasi Dan Asimetri Informasi Terhadap Kecenderungan Kecurangan Akuntansi (Studi Empiris Pada Universitas Muhammadiyah Surakarta). Fakultas Ekonomi Dan Bisnis Universitas Muhammadiyah Surakarta.

Jensen, M. C., \& Meckling, W. H. (1976). Theory of the Firm: Managerial Behavior, Agency Costs And Ownership Structure. Journal of Financial Economics, 3(4), 305-360. https:/ / doi.org/http:/ / dx.doi.org/10.1016/0304-405X(76)90026-X

Luthans, F. (2011). Organazational Behavior 12th ed. Irwin McGraw-Hill.

Miasa. (2019). Ketua Pengawas LPD Desa Pekraman Selat Diadili Kasus Korupsi. Bali Post. https://www.balipost.com/news

Monigka, F. (2010). Pengaruh Ketaatan akuntansi, Sistem Pengendalian Intern, Moralitas Manajemen dan Kesesuaian Kompensasi Terhadap Kecenderungan Kecurangan Akuntansi (Studi Empiris pada Perusahaan BUMN di Kota Padang). FE UNP : Padang.

Permatasari, D. E., Kurrohman, T., \& Kartika. (2017). Analisis Faktor-Faktor yang Mempengaruhi Terjadinya Kecenderungan Kecurangan (Fraud) di Sektor Pemerintah. Jurnal Keuangan Dan Perbankan, 14(1), 37-44.

Pratiwi, T. (2018). Pengaruh Kesesuaian Kompensasi, Sistem Pengendalian Internal, Pemanfaatan Teknologi Informasi, Budaya Etis Organisasi Dan Kompetensi Terhadap Fraud Pada Pemerintah Daerah. Fakultas Ekonomi Dan Bisnis Universitas Lampung Bandar Lampung.

Putra, I. P. A. P. E., \& Latrini, M. Y. (2018). Pengaruh Pengendalian Internal, Budaya Organisasi, dan Moralitas pada Kecenderungan Kecurangan (Fraud) di LPD se-Kabupaten Gianyar. E-Jurnal Akuntansi, 25(3), 2155-2184. https:// doi.org/10.24843/ eja.2018.v25.i03.p20

Putu, N., Murtining, S., \& Dwiyanti, K. T. (2019). Pengaruh love of money , machiavellian, dan equity sensitivity terhadap persepsi etika penggelapan pajak (Tax Evasion) FakultasaEkonomirdan BisnisaUniversitasaPendidikan Nasionalf (Undiknas), Bali , Indonesia AB. E-Jurnal Akuntansi Universitas Udayana, 26, 1412-1435.

Randiza, I., Kamaliah, K., \& Anisma, Y. (2016). Pengaruh Pengendalian Internal, Asimetri Informasi, Moralitas Aparat Pemerintah Dan Ketaatan Aturan Terhadap Kecenderungan Kecurangan Akuntansi (Studi Kasus Pada SKPD Kab. Indragiri Hilir). Jurnal Online Mahasiswa Fakultas Ekonomi Universitas Riau, 3(1).

Riahi, A., \& Belkaoui. (2000). Teori Akuntansi. Salemba Empat.

Saftarini, P. R., Yuniarta, G. A., \& Sinarwati, N. K. (2015). Pengaruh Efektivitas Pengendalian Internal, Asimetri Informasi Dan Implementasi Good Governance Terhadap Kecenderungan Kecurangan (Fraud) Akuntansi (Studi Empiris Pada Skpd Di Kabupaten Bangli). E-Jurnal S1 Ak Universitas Pendidikan Ganesha, 3(1). 
Sayyid, A. (2015). Pemeriksaan Fraud Dalam Akuntansi Forensik Dan Audit Investigatif. Al-Banjari: Jurnal Ilmiah Ilmu-Ilmu Keislaman, 12(2). https://doi.org/10.18592/al-banjari.v13i2.395

Shintadevi, P. F. (2016). Pengaruh Keefektifan Pengendalian Internal, Ketaatan Aturan Akuntansi Dan Kesesuaian Kompensasi Terhadap Kecenderungan Kecurangan Akuntansi Dengan Perilaku Tidak Etis Sebagai Variabel Intervening. Nominal, Barometer Riset Akuntansi Dan Manajemen, 4(2), 10-17. https://doi.org/10.21831/nominal.v4i2.8003

Suarcaya, I. B. K., Prayudi, M. A., \& Herawati, N. T. (2018). Pengaruh Kesesuaian Kompensasi, Pengendalian Internal, Dan Perilaku Tidak Etis Terhadap Kecenderungan Kecurangan (Fraud) (Studi Kasus Pada Persepsi Pegawai Koperasi Simpan Pinjam (Ksp) Se-Kecamatan Buleleng). Jimat (Jurnal Ilmiah Mahasiswa Akuntansi) Undiksha, 8(2).

Sugiyono. (2016). Statistika Untuk Penelitian. Bandung: AlfaBeta.

Thoyibatun, S. (2012). Faktor-Faktor Yang Berpengaruh Terhadap Perilaku Tidak Etis Dan Kecenderungan Kecurangan Akuntansi Serta Akibatnya Terhadap Kinerja Organisasi. Ekuitas (Jurnal Ekonomi Dan Keuangan), 6(12), 245-260. https:// doi.org/10.24034/j25485024.y2012.v16.i2.2324

Udayani, A. A. K. F. (2016). Pengaruh Pengendalian Internal dan Moralitas Individu Pada Kecenderungan Kecurangan Akuntansi (Studi pada Villa di Kawasan Umalas). Skripsi Fakultas Ekonomi dan Bisnis Universitas Udayana.

Utomo, L. P. (2018). Jurnal Akuntansi dan Pajak, 19 (01), 2018, 77-88 Kecurangan Dalam Laporan Keuangan “Menguji Teori Fraud Triangle." Jurnal Akuntansi Dan Pajak, 19(1).

Wright, P., Mukherji, A., \& Kroll, M. J. (2001). A reexamination of agency theory assumptions: Extensions and extrapolations. Journal of Socio-Economics, 30(5), 413-429. https:/ / doi.org/10.1016/S1053-5357(01)00102-0 